УДК 811.161.2’27:316.77-057.87-054.6

\title{
УКРАЇНСЬКА МОВА: КРИТЕРІЇ, ПОКАЗНИКИ, РІВНІ СФОРМОВАНОСТІ МІЖКУЛЬТУРНОЇ КОМПЕТЕНТНОСТІ МІЖКУЛЬТУРНОЇ КОМУНІКАЦІЇ СТУДЕНТІВ-ІНОЗЕМЦІВ
}

\section{Світлана Костюк}

\author{
Криворізький наиіональний університет \\ Kryvyi Rih National University \\ вул. В. Матусевича, 11, Кривий Ріг, 50027, Україна \\ skostyukss@gmail.com
}

Костюк С. Українська мова: критерії, показники, рівні сформованості міжкультурної компетентності міжкультурної комунікації студентів-іноземців

Статтю присвячено проблемі визначення критеріїв, показників та рівнів сформованості міжкультурної компетентності міжкультурної комунікації студентів-іноземців у процесі навчання української мови. Проаналізовано погляди науковців щодо структури міжкультурної компетентності, виокремлено критерії сформованості міжкультурної компетентності студентівіноземців, показники задля коректного оцінювання рівня сформованості міжкультурної компетентності міжкультурної комунікації.

Ключові слова: міжкультурна комунікація, міжкультурна компетентність, критерії, показники, рівні сформованості міжкультурної компетентності, українська мова як іноземна.

Костюк С. Украинский язык: критерии, показатели, уровни сформированности межкультурной компетентности межкультурной коммуникации студентов-иностранцев

Статья посвящена проблеме определения критериев, показателей и уровней сформированности межкультурной компетентности межкультурной коммуникации студентов-иностранцев в процессе изучения украинского языка. Проанализированы мнения ученых о структуре межкультурной компетентности, выделены критерии сформированности межкультурной компетентности студентов-иностранцев, показатели для корректной оценки уровня сформированности межкультурной компетентности межкультурной коммуникации.

Ключевые слова: межкультурная коммуникация, межкультурная компетентность, критерии, показатели, уровни сформированности межкультурной компетентнгости, украинский язык как иностранный. 
Kostiuk S. Ukrainian language: criteria, factors and levels of the development of foreign students' intercultural competence of intercultural communication

The article deals with the defining of criteria, factors and levels of the development of foreign students' intercultural competence of intercultural communication during the Ukrainian language training. Viewpoints of scientists on the intercultural competence structure and peculiarities of the criteria choice are analyzed. Motivational-value, cognitive, professional and communicative, linguoculturological criteria of intercultural competence development were signed out. Motivational-value criterion represents the system of motives and values that promote students to master intercultural communication competences treat them as necessary in their future public and professional activities. Cognitive characterizes the achievements of foreign students, their understanding of essence, content, goals of intercultural communication. Professional and communicative criterion determines the ability to apply the acquired knowledge of the language, culture, norms of communication in practice. Linguoculturological criterion represents the level of foreign students' language, culture, history, social and political values of the studied country awareness. The conducted research allowed to determine the levels of intercultural communication competences: reproductive, consciously-situational, active and creative.

Key words: intercultural communication, intercultural competence, criteria, factors, levels of development, Ukrainian as a foreign.

\section{Постановка проблеми та її зв'язок із важливими} науковими завданнями. У нормативно-правових актах (Закон України "Про вищу освіту", Національна доктрина розвиту освіти України у XXI столітті, Концепція мовної підготовки іноземців) визначено пріоритетну освітню стратегію виховання гармонійно розвиненої особистості, здатної до цивілізованої й успішної взаємодії в полікультурному світі. Розвитку сучасного суспільства сприяє встановлення міжкультурного спілкування, що передбачає глибоке розуміння культури інших країн, ознайомлення з їхніми цінностями, обмін лінгвосоціокультурною інформацією. Тому першочерговим завданням освіти є формування особистості, здатної пізнавати, розуміти, сприймати культуру через міжкультурну комунікацію.

Реформування системи освіти України 3 урахуванням Європейських стандартів і досвіду, упровадження компетентнісної парадигми створюють сприятливі умови для формування життєво необхідних для студентів-іноземців компетентностей, з-поміж яких чільне місце посідає 
міжкультурна, яка розвиває здатність орієнтуватися в різних видах культур, системах цінностей, реалізовувати знання в межах діалогу культур, пристосовуватися до умов іншої культури, спільної діяльності з представниками інших культур, оцінювати комунікативну ситуацію та співвідносити комунікативні наміри з передбачуваним вибором стратегій, які застосовуються в ситуаціях міжкультурного спілкування [Kostiuk / Костюк $2018: 8$ ].

Необхідність формування міжкультурної компетентності задля кращого розуміння й опанування мовою студентамиіноземцями вимагає узгодження критеріїв оцінювання набутої компетентності.

Аналіз останніх досліджень та публікацій. Студіювання наукових джерел із філософії, лінгвістики, психології, педагогіки, лінгводидактики дає підстави стверджувати, що інтерес науковців до питань формування компетентностей міжкультурної комунікації зростає. 3-поміж досліджень, у яких 3'ясовано різні аспекти цієї проблеми, можна виокремити такі наукові напрями: узаємозв'язок мови, культури та комунікації [Vereshchagin / Верещагін 1990]; формування компетентностей [Palchikova/ Пальчикова 2012]; розвиток мовної освіти через упровадження компетентнісного підходу [Karaman/ Караман 2011]; навчання української мови як іноземної [Bakum / Бакум 2014]; визначення критеріїв, показників та рівнів сформованості компонентів діяльності [Zuienko / Зуєнко 2015; Chumak / Чумак 2011].

Мета й завдання дослідження. Розробити критерії, показники та рівні сформованості міжкультурної компетентності міжкультурної комунікації студентів-іноземців під час навчання української мови.

Виклад основного матеріалу дослідження. У процесі формування міжкультурної компетентності студентів-іноземців необхідно ураховувати критерії і показники, що передбачають оцінювання динаміки навчальних досягнень студентів та результативність застосованої методики розвитку означеної компетентності, забезпечують реалізацію індивідуального 
підходу в освіті, можливість реалізувати тісні міжпредметні зв'язки упродовж усього навчання тощо.

У науковій літературі $є$ різні підходи до визначення критеріїв, показників та рівнів сформованості компонентів діяльності (О. Абдуліна, М. Байрам, Н. Бєляков, П. Гальперін, В. Гудикунст, В. Дороз, І. Зимня, В. Зоріна, С. Пахотіна, Н. Тализіна, Л. Чумак). Під поняттям “критерій” розуміють істотну, характерну ознаку, на підставі якої відбувається оцінювання, визначення або класифікація чогось; мірило визначення або класифікації чогось [Slovnyk ukrainskoi movy / Словник української мови $1973: 249]$. Відповідно, “критерій” витлумачуємо як характерну ознаку, завдяки якій можна оцінити стан сформованості міжкультурної компетентності міжкультурної комунікації студентів-іноземців.

Оцінювання педагогічних явищ вимагає уніфікованої системи критеріїв, що мають відповідати певним вимогам: об'єктивність, надійність, простота виміру. 3-поміж додаткових ознак науковці виокремлюють:

- компактність, зручність у використанні; поєднання якісних і кількісних методів оцінювання, які пов'язані не лише iз зовнішніми діями і вчинками, але й із внутрішнім світом людини, що самовизначається; їхня зрозумілість як для спеціаліста, так і для суб' єкта самовизначення; прогностичність, що дозволяє не лише оцінити певний рівень самовизначення, але й простежити його динаміку [Pryazhnikov/ Пряжніков 1997 : 239];

- $\epsilon$ результатом спільного обговорення та співпраці усебічно інформованих експертів; мають грунтуватися на даних результатів іспитів; установлення критеріїв вимагає експертних висновків [Bulah / Булах 1997 : 235];

- на визначення критерії не повинна впливати думка суб'єків; ознаки мають бути сталими; основний зміст критеріїв характеризується системою взаємопов'язаних ознак [Bloshchynskyi / Блощинський 2001 : 75].

Проблемі визначення критеріїв оцінювання ефективності навчання присвячено праці С. Волинського, І. Зозулі, В. Лапіної, К. Пригожиної, Н. Самойленко, Л. Хіценко, Л. Чумак та ін.

(C) С. Костюк, 2019. 
Добираючи критерії для вимірювання полікультурної компетентності, Л. Чумак та I. Зозуля виокремлюють такі: мотиваційний (виявлення моральних якостей, толерантності та чуйності у стосунках); когнітивний (знання моральних норм, правил i способів взаємодії між людьми, культура міжособистісного спілкування); поведінковий (використання умінь, навичок, тактик толерантної поведінки) [Zozulia / Зозуля 2012; Chumak / Чумак 2011].

I. Дирда до запропонованих критеріїв додає аксіологічний (сукупність національних та загальнолюдських цінностей, знання про систему моральних, естетичних та інших цінностей, толерантність, гуманізм, національну й етнічну самосвідомість) [Dyrda / Дирда 2017 : 461].

3-поміж критеріїв оцінювання міри сформованості міжкультурної компетентності Н. Самойленко визначає: ціннісно-мотиваційний (цінності i мотиви, необхідні для опанування та реалізації міжкультурного спілкування); когнітивний (знання, необхідні для міжкультурної взаємодії, навички коректної поведінки); операційно-технологічний (визначає рівень сформованості умінь та навичок, які характеризують міжкультурну компетентність студента); рефлексивний (оцінювання процесу міжкультурного спілкування), особистісний (якості студента, що впливають на міжкультурне спілкування) [Samoilenko / Самойленко 2014: 6]. К. Пригожина пропонує доповнити означені критерії такими: афективний (сформованість загальної культурної обізнаності) та поведінковий (сформованість навичок та вмінь використання набутих знань у ситуаціях особистісного та професійного спілкування) [Prygozhina / Пригожина 2011 : 160].

Л. Хіценко розглядає три критерії сформованості соціокультурної компетентності: когнітивний (визначає знання культури спілкування, сформованість моральних та етичних норм поведінки, мовних правил спілкування, міру розуміння схожості й відмінності культур); операційно-функційний (вимірює здатність застосовувати соціокультурні знання у процесі комунікативної діяльності, аналізувати й контролювати конфліктні ситуації, вибудовувати стратегію їх подолання, 
адаптуватися в ситуаціях соціально-професійної взаємодії); емоційний (соціокультурна неупередженість, толерантність, критичне ставлення до своїх вчинків) [Hitsenko/ Хіценко 2016 : 149].

Рівень сформованості мовленнєвої компетентності В. Лапіна визначає за чотирма видами мовленнєвої діяльності та виокремлює такі критерії: розуміти й розпізнавати інформацію, ураховувати соціальні й вікові особливості учасників комунікації, прогнозувати результат висловлення (аудіювання); розуміти зміст прочитаного, визначати ідею тексту та позицію автора (читання); доречно використовувати мовні засоби задля формування висловлення й активної участі в комунікативному акті (говоріння); створювати письмове висловлення, дотримуючись структури, стилістики, лексичної і граматичної коректності тексту (письмо) [Lapina / Лапіна 2012 : 173-174].

3-поміж критеріїв сформованості іншомовної комунікативної компетентності Л. Нагорнюк виокремлює: мотиваційний, лексико-граматичної правильності, професійний, соціокультурний, стратегічний, критерій комунікабельності [Nagornuk / Нагорнюк].

Відповідно, апелюючи до праць науковців (І. Зозуля, I. Дирда, К. Пригожина, Н. Самойленко, А. Садохін, Л. Хіценко), визначимо такі критерії сформованості міжкультурної компетентності міжкультурної комунікації студентів-іноземців у процесі навчання української мови на основному етапі: мотиваційно-ціннісний, когнітивний, професійно-комунікативний та лінгвокультурознавчий.

На основі аналізу праць щодо вибору критеріїв можна зробити висновок про те, що вони відображають структурні компоненти міжкультурної комунікації, уможливлюють їх якісну оцінку, ураховують особливості педагогічних заходів, спрямованих на формування компетентностей міжкультурної комунікації студентів-іноземців у процесі навчання української мови.

Докладний аналіз наукових праць, присвячених питанням міжкультурної комунікації (Ж. Горіна, О. Пальчикова, В. Сафонова,) та визначенню структури компетентностей 
(I. Закір'янова, С. Омельчук, П. Сулейманова), дають підстави стверджувати, що “міжкультурна комунікація"-складний процес спілкування між представниками різних культур, який складається з компонентів та залежить від впливу різноманітних чинників (мовних знань, правил побудови висловлення, комунікативних стратегій, культури, норм та цінностей, прийнятих у певному суспільстві). Основою міжкультурної комунікації є: мова (репрезентує культурний код народу); культура (впливає на особливості процесу спілкування); особистість (є безпосереднім учасником комунікації). Відповідно, компетентності міжкультурної комунікації можуть бути презентовані поєднанням таких компонентів: ціннісний, пізнавальний, дієвий та культурологічний.

У межах міжкультурної компетентності цүіннісний компонент відображає сформованість навчально-пізнавальних, професійних i соціальних мотивів, розуміння значення міжкультурної взаємодії у процесі особистісного та професійного становлення, визнання рівноправності культур через зіставлення й аналіз. Ціннісний компонент передбачає усвідомлення:

- цінності культур сучасного світу;

- значення міжкультурного спілкування для професійного становлення й особистого розвитку;

- зв'язку між культурою, народом i формуванням особистості - "медіатора культур";

- важливості толерантності у процесі налагодження міжкультурних взаємин.

Пізнавальний компонент міжкультурної компетентності містить комплекс знань (мова, культура, історія, правила етикету, соціально-культурні норми), необхідні для взаємодії 3 представниками інших культур, знання стратегій запобігання конфліктів у міжособистісній та професійній сферах. До означеного компонента входять:

- знання особливостей комунікативної поведінки представників інших культур;

- аналіз та запобігання стереотипізації щодо іншої культури та їі носіїв; 
- володіння знаннями з мови, культури, історії для участі у процесі міжкультурної комунікації;

- знання системи цінностей i норм задля орієнтації в ситуації міжкультурного спілкування i розуміння сутності повідомлення;

- вивчення змісту національної культури й усвідомлення іiі особливостей.

Дієвий компонент міжкультурної компетентності передбачає уміння застосовувати стратегії спілкування для запобігання конфліктних ситуацій, що відрізняються від прийнятих у межах певної культури та зумовлюють успіх чи невдачу комунікативного акту. До складу компонента входять уміння:

- використовувати знання 3 мови, культури, комунікативних стратегій у процесі міжкультурної комунікації;

- аналізувати та використовувати комунікативні стратегії для запобігання конфліктних ситуацій;

- моделювати монологічні й діалогічні висловлення 3 урахуванням культурних особливостей представників інших національностей; взаємодії.

- аналізувати й оцінювати результати міжкультурної

Культурологічний компонент міжкультурної компетентності містить знання з історії, культури, суспільних та політичних цінностей країн, усвідомлення ролі культури у процесі міжнаціонального спілкування. Означений компонент передбачає:

- розуміння невербальних засобів для правильної інтерпретації повідомлення;

- використання виражальних можливостей української мови у процесі міжкультурного спілкування;

- використання знань про культуру та цінності інших народів у процесі міжкультурного спілкування задля досягнення його результату;

- позитивне сприйняття відмінностей у культурних цінностях, нормах представників інших лінгвокультурних спільнот;

(C) С. Костюк, 2019. 
- уміння оцінювати відповідність своїх учинків загальнолюдським моральним нормам, усувати невідповідність цим нормам.

Кожен із компонентів i його критеріїв необхідно розглянути через систему показників, які їх характеризують. Н. Повесьма визначає “показник” як характеристику, що найбільш повно з'ясовує сутність критерію [Povesma / Повесьма 2011 : 100]. На думку В. Тернопільської та О. Дерев'янко, це кількісні або якісні характеристики сформованості якості, властивості, ознаки об'єкта, що вивчається, ступінь сформованості того чи того критерію [Ternopilska / Тернопільська 2010 : 265].

До кожного 3 критеріїв визначимо показники, які характеризують рівні сформованості компетентностей міжкультурної комунікації студентів-іноземців.

Мотиваційно-ціннісний критерій відображає систему мотивів і цінностей студента, що спонукає його до опанування компетентностями міжкультурної комунікації, ставлення до них як до необхідних у майбутній суспільній i професійній діяльності. Показниками мотиваційно-ціннісного критерію є:

- усвідомлення необхідності отримання освіти;

- бажання послуговуватися соціокультурною інформацією в соціальному і професійному середовищах;

- позитивна мотивація усунення міжкультурних непорозумінь;

- мотивація вдосконалення компетентностей;

- позитивне сприйняття багатоманітності культур.

Когнітивний критерій характеризує рівень засвоєння студентами-іноземцями знань, розуміння сутності, змісту, цілей міжкультурної комунікації. Показниками означеного критерію $€$ :

- володіння знаннями про сутність, зміст і цілі міжкультурної комунікації;

- сформованість системи соціально-культурних знань (із культури, історії, традицій, державних символів), необхідних для ефективного міжкультурного спілкування, їхня міцність і усвідомленість; 
- знання про міжкультурну взаємодію, моральні норми, цінності, заборони.

За професійно-комунікативним критерієм визначають уміння застосовувати набуті знання 3 мови, культури, норм спілкування, професійні знання на практиці. Означений критерій характеризується такими показниками:

- застосування фахових і соціокультурних знань в умовах комунікації з представниками інших культур;

- участь у розмові відповідно до ситуації спілкування;

- прогнозування й проектування висловлень на соціальнопобутові та фахові теми;

- розвинена поведінкова гнучкість.

Лінгвокультурознавчий критерій відповідає за рівень обізнаності студентів-іноземців із мовою, культурою, історією, суспільними та політичними цінностями країни, мова якої вивчається. 3-поміж показників виокремимо:

- знання особливостей рідної культури й культури іншої країни;

- мовно-культурна грамотність;

- володіння знаннями про мовленнєві одиниці (еквівалентні / безеквівалентні), їх доречне використання у мовленні.

Міру сформованості показника характеризує рівень. У наукових джерелах знаходимо такі визначення цього поняття: ступінь якості, величина, досягнуті в чому-небудь [Slovnyk ukrainskoi movy / Словник української мови 1073:547]. Витлумачуємо його як мірило сформованості компетентностей міжкультурної комунікації студентів-іноземців. Відповідно до критеріїв та показників встановлюються рівні сформованості компетентностей міжкультурної комунікації студентівіноземців.

Звернемося до праць науковців, у яких розглянуто градації рівнів сформованості полікультурної, міжкультурної, комунікативної компетентностей.

У дослідженні сформованості полікультурної компетентності: високий, середній та низький. Високий рівень вирізняється крос-

() С. Костюк, 2019. 
культурною грамотністю, визнанням громадянських цінностей, державних символів України, розвиненими навичками монологічного (проектування та створення висловлення) i діалогічного (уміють брати участь у розмові відповідно до заданої ситуації) мовлення; високим рівнем сформованості гуманістичних цінностей, моральних та громадянських ідеалів, готовністю до поглиблення знань про Україну, сприйняття української розмаїтості; відкритістю до української культури, толерантностю (визнають і приймають культуру іншого).

Середній рівень характеризується достатніми уявленнями про історію України, ऑï культуру, традиції, громадянські цінності. Студенти мають сформовані навички діалогічного спілкування, беруть участь у розмові, але не завжди можуть використати свій мовленнєвий досвід, уміють створювати монологічні висловлення, дотримуються правил українського мовленнєвого етикету. Розуміють необхідність урахування у своїй поведінці правил спілкування, виявляють ініціативу у встановленні міжкультурного контакту задля досягнення порозуміння.

Низький рівень вирізняється полікультурною неграмотністю студентів, недостатнім рівнем сформованості уявлень про моральні й загальнодержавні цінності України, виявленням упередженості у ставленні до навколишнього світу. Студенти не готові до сприйняття української культури та культурної взаємодії у спілкуванні 3 представниками інших національностей, у них слабко сформовані навички діалогічного та монологічного спілкування [Zozulia / Зозуля 2012 : 8].

Залежно від міри та якості вияву міжкультурної комунікації Н. Зуєнко виокремлює три рівні: номінальний, пізнавальний, творчий. 3 позиції науковця, творчий рівень визначається високим рівнем ділового мовлення, розвинутими комунікативними навичками, потребою в самовдосконаленні, здатністю творчо розв'язувати професійні та комунікативні завдання.

Пізнавальний рівень міжкультурної комунікації характеризується взаємозв'язком професійних знань і умінь та рівнем міжкультурної комунікативної компетентності. 
Студентам цього рівня притаманні спрямованість на досягнення у професійній сфері, середній рівень розвитку комунікативних навичок, володіння діловим мовленням на достатньому рівні.

Номінальний рівень - обмеженість у розумінні загальнолюдських цінностей, негнучкість у сприйнятті чужої культури, повільна зміна уявлень під час змін умов життя. Студенти 3 номінальним рівнем міжкультурної комунікативної компетентності мають низький рівень успішності, не усвідомлюють взаємозв'язок між рівнем комунікативної культури та майбутньою професійною реалізацією. Для них характерна низька комунікабельність i зацікавленість у формуванні компетентностей міжкультурної комунікації [Zuienko / Зуєнко 2015 : 64-69].

Н. Самойленко ураховує низку критеріїв сформованості міжкультурної компетентності (ставлення студентів до власної культури й мови та культури й мови, що вивчаються); наявність знань про загальноприйняті моделі поведінки та спілкування, притаманні мові і культурі, що вивчається; уміння порівнювати явища двох культур; прагнення здобувати нові знання та використовувати набуті для взаємодії 3 представниками іншомовної культури; уміння оцінювати явища і події, притаманні рідній та іншомовній культурі). 3 огляду на це виокремлює такі рівні: елементарний (когнітивні уявлення, навички іншомовного спілкування), достатній (сформованість когнітивної бази, навичок, умінь, деяких якостей поведінки), просунутий (мотиви, уміння, поведінкові якості, міжкультурна діяльність) [Samoilenko / Самойленко 2014 : 10-11].

Досліджуючи міру оволодіння полікультурними знаннями, Л. Чумак визначає активно-творчий (високий), усвідомленно-ситуативний (середній), репродуктивний (низький) рівні. Для активно-творчого рівня характерне сформоване стійке ціннісне ставлення до людства, навколишніх, до себе; знання про сутність понять “моральні цінності”, “національна і загальнолюдська культура", “толерантність”, готовність до діалогу та співробітництва 3 представниками різних культур за збереження власної ідентичності; готовність прийти на допомогу людям різних 
національностей. Усвідомлено-ситуативний рівень презентує часткові уявлення про важливість вияву моральності й толерантності в суспільстві; фрагментарну сформованість ціннісного ставлення до представників інших національностей; часткову готовність до діалогу культур, співробітництва, позитивної взаємодії, частково сформоване бажання прийти на допомогу. Репродуктивний рівень стосується тих, у кого відсутня мотивація до розуміння необхідності моральності й толерантності як особистісно-моральних якостей; знання про національні й загальнолюдські моральні цінності й толерантність поверхові або відсутні, не сформоване ціннісне ставлення до представників інших національностей [Chumak / Чумак 2011 : 9-10].

Провідною метою методики навчання української мови як іноземної $\epsilon$ формування особистості, здатної і готової до міжкультурного діалогу, що виявляє толерантне ставлення до представників іншої культурної спільноти, здатна адекватно взаємодіяти в ситуаціях міжкультурної комунікації. Ситуації спілкування передбачають креативне використання певних знань. Тому, проаналізувавши градації рівнів сформованості компетентностей, обрано репродуктивний, усвідомленоситуативний та активно-творчий рівні, як такі, що найбільш актуально й конкретно описують рівень сформованості певної компетентності.

Репродуктивний рівень відзначається наявністю вибіркових мовних i культурних знань 3 предмета, що призводить до помилок під час спілкування; студенти не розуміють культурного забарвлення та послуговуються правилами й нормами поведінки, притаманними рідній мові та культурі. Загалом студенти мають достатній лексичний запас (розуміють текст, можуть відповідати на запитання, логічно і граматично правильно будують висловлення), але мають труднощі в аудіюванні, розумінні автентичних текстів, спілкуванні з представниками іншої культури (ускладнення, непорозуміння, певні бар'єри), часто не розпізнають невербальні та паравербальні сигнали, слабко володіють навичками писемного мовлення. 
Усвідомлено-ситуативний - передбачає

володіння поглибленими знаннями про мовну систему і культуру України, якими студент послуговується у побутовій, навчальній і професійній сферах діяльності, та налаштованість на процес пізнання мови й культури. Суб'єкт навчання розуміє тексти різних жанрів, може виокремити необхідну інформацію, скласти план, визначити ключові слова, має розвинені навички монологічного та діалогічного спілкування, розуміє необхідність дотримуватися правил спілкування, виявляє ініціативу у встановленні міжкультурного контакту. Означений рівень характеризується незначними труднощами в оцінюванні поведінки представників іншої культури.

Активно-творчий рівень характеризується достатньою кількістю навичок для вільного спілкування 3 урахуванням комунікативних стратегій та правил етикету, притаманних іншій культурі. Суб'єкт вільно володіє лексичним запасом, може аналізувати національну специфіку поведінки, творчо використовувати міжкультурні знання в різних ситуаціях спілкування, застосовувати фразеологічні звороти та ідіоматичні вирази задля підтримання бесіди та іiі урізноманітнення. Цей рівень визначається потребою у самовдосконаленні та здатністю творчо розв'язувати професійні й комунікативні завдання.

Отже, проаналізуємо відповідність критеріїв, показників та рівнів сформованості міжкультурної компетентності міжкультурної комунікації задля адекватного оцінювання студентів-іноземців у процесі вивчення української мови на основному етапі навчання.

Мотиваційно-ціннісний критерій охоплює цінності та мотиви особистості, які сприяють успішній комунікації в міжособистісній, професійній та міжкультурній сферах. Означений критерій характеризує сформованість в іноземних студентів бажання більше дізнатися про Україну, іiі мову, культуру, а також міру ціннісного визнання іншої культури. Показниками цього критерію на репродуктивному рівні вважаємо:

(C) С. Костюк, 2019. 
- низький рівень сформованості гуманістичних цінностей, моральних і громадських ідеалів українців як важливого чинника порозуміння між народами;

- незначний інтерес до вивчення української мови та культури;

- слабке бажання підвищувати свій рівень мовних i соціокультурних знань задля особистісного та професійного зростання.

Для показників мотиваційно-ціннісного критерію на усвідомлено-ситуативному рівні характерними є:

- усвідомлення необхідності дотримуватися у своїй поведінці норм і правил спілкування;

- налаштованість на процес пізнання мови та культури (усвідомлення важливості збагачення знаннями для подальшого послуговування ними у професійній та соціальній сферах);

- дотримання норм власної культури під час оцінювання іноземної.

Активно-творчому рівню відповідають такі показники сформованості міжкультурної компетентності міжкультурної комунікації:

- бажання підвищувати рівень знань про українську мову та культуру, використовувати різні джерела і застосовувати набуті знання й уміння в усній та писемній формах;

- готовність до адекватної поведінки під час міжкультурного контакту, уміння творчо і швидко долати складні ситуації;

- уміння коректно оцінювати, зіставляти й аналізувати характерні прояви власної та української культури в різних ситуаціях, виказувати толерантні судження, стриманість щодо норм і цінностей, які відрізняються від власної культури.

Когнітивний критерій визначає міру володіння студентом сукупністю знань, необхідних для ефективної міжкультурної взаємодії 3 представниками іншої, української культури. Показниками когнітивного критерію на репродуктивному рівні $€$ :

- слабкі знання про людські взаємини, моральні норми та норми-заборони; 
- задовільні знання з історії України, ії культури, традицій і фольклору;

- обмежене уявлення про громадянські цінності, слабко сформована повага до державних символів України.

Для усвідомлено-ситуативного рівня характерними показниками вважаємо:

- поглиблені знання про моральні норми, правила, способи взаємодії між людьми, котрі зорієнтовують особу у виборі дій;

- достатній рівень знань про культуру України, соціальні особливості, традиції, спосіб життя, якими студент послуговується в побутовій та навчальній сферах;

- знання основ міжкультурної комунікації (стилі спілкування, мова жестів);

- уміння диференціювати спільне та відмінне у власній та іноземній культурах.

Активно-творчому рівню відповідають такі показники сформованості міжкультурної компетентності міжкультурної комунікації:

- достатньо сформовані навички для вільного спілкування 3 урахуванням комунікативних стратегій та правил етикету, притаманних іншій культурі;

- глибокі знання і розуміння соціокультурної інформації (географічної, морально-правової, історичної, культурної);

- уміння аналізувати власну діяльність у процесі міжкультурного спілкування;

- володіння навичками ефективного слухання та конструктивного подолання конфліктів для застосування в міжособистісній і професійній сферах.

Професійно-комунікативний критерій характеризує здатність іноземних студентів опанувати українську мову, використовувати iї 3 комунікативною метою в соціальнопобутовій і професійній сферах. Показниками цього критерію на репродуктивному рівні $\epsilon$ :

- уявлення про культуру поведінки, спілкування, мовлення в українському суспільстві;

- розвиненість навичок проектувати й створювати мовленнєві висловлення;

(C) С. Костюк, 2019. 
- уміння брати участь у розмові згідно із заданою ситуацією спілкування, використовуючи мовний досвід;

- нечастотне вживання лексичних одиниць із національнокультурним забарвленням відповідно до ситуації спілкування;

- задовільне опанування основ невербальної комунікації із подальшим використанням.

У межах усвідомлено-ситуативного рівня основними показниками означеного критерію вважаємо:

- розвинені навички монологічного мовлення, вміння виокремити та відтворити необхідну інформацію, спираючись на складений план або запитання;

- сформовані навички діалогічного мовлення, розуміння текстів різних жанрів, відтворення діалогу за зразком із використанням великого обсягу відомої та нової лексики;

- дотримання правил українського мовленнєвого етикету.

Для активно-творчого рівня основними показниками $є$ :

- вільне спілкування 3 урахуванням комунікативних стратегій та правил етикету, притаманних іншій культурі;

- автоматизовані навички монологічного та діалогічного мовлення (вільне володіння матеріалом та здатність його застосовувати без уживання підготовлених опор);

- застосування фразеологічних зворотів та ідіоматичних виразів для урізноманітнення спілкування.

Лінгвокультурознавчий критерій відповідає за рівень обізнаності студентів-іноземців 3 мовно-культурними нормами країни, мова якої вивчається. У межах репродуктивного рівня виокремлюємо такі показники:

- низький рівень мовно-культурної грамотності;

- незначний інтерес до порівняння особливостей рідної культури та культури іншої країни;

- слабке бажання оцінювати культурні надбання свого краю та інших країн, сприймати та опановувати їх;

- недостатньо сформовані компетентності 3 чотирьох видів мовленнєвої діяльності.

Усвідомлено-ситуативний рівень має такі характеристики:

- усвідомлення ролі культури в мистецтві міжнаціонального спілкування; 
- налаштованість на підвищення мовних i мовленнєвих умінь і навичок, що передбачають вільне поєднання на практиці лінгвістичних та мовленнєвих умінь;

- терпимість до проявів “іншої” культури в навчальному матеріалі та міжкультурному спілкуванні.

У межах активно-творчого рівня визначаємо:

- здатність примножувати національні культурні цінності;

- уміння послуговуватися мовою відповідно до морфологічних, синтаксичних, лексичних, стилістичних норм;

- сформовані навички 3 аудіювання, читання, письма, говоріння.

Висновки та перспективи подальших наукових розвідок. Виокремлення критеріїв та їх показників дозволяє точно описати рівні сформованості міжкультурної компетентності міжкультурної комунікації студентів-іноземців під час навчання української мови. Описані критерії $\epsilon$ своєрідним мірилом для визначення ефективності формування означеної компетентності, розроблення методики навчання мови як іноземної, що допомагає скоригувати процес формування міжкультурної компетентності міжкультурної комунікації студентів-іноземців.

Перспективу подальшого дослідження вбачаємо в поглибленому аналізі рівнів сформованості міжкультурної компетентності на основі виокремлених критеріїв та показників.

\section{Література}

1. Бакум 3. П., Пальчикова А. А. Роль языковой картины мира в обучении иностранных студентов украинскому языку. Acta humanistica et scientifica universitatis sungio kiotiensis: материалы докладов и сообщений Международного форума "Социокультурные и филологические аспекты в образовательном и научном контексте”. Киото : “Tanaka Print”, 2014. С. 60-63.

2. Блощинський I. Г. Обгрунтування критеріїв і показників ефективності процесу формування адекватної самооцінки курсантів у навчальному процесі ВВЗО. Наукові записки. Вінниця : ВАТ “Віноблдрукарня”. 2001. Вип. 4. С. 74-76.

3. Булах І. Є. Сучасні підходи до встановлення критерію “склав / не склав" у системі американських медичних ліцензійних іспитів. Педагогіка $i$ психологія. 1997. № 3. С. 230-236. 
4. Верещагін Е. М., Костомаров В.Г. Язык и культура : Лингвострановедение в преподавании русского языка как иностранного. 4-е изд. Москва : Рус. яз., 1990. 246 с.

5. Дирда I. А. Критерії, показники та рівні розвитку полікультурної компетентності студентів-іноземців у процесі навчання української мови. Філологічні студії : Науковий вісник Криворізького держсавного педагогічного університету : зб. наук. праць. 2017. Вип. 16. С. 459-465.

6. Зозуля І. С. Полікультурне виховання іноземних студентів вищих технічних навчальних закладів : автореф. дис. ... канд. пед. наук : 13.00.07. Вінниця, 2012. 21 с.

7. Зуєнко Н. О. Критеріально-рівневий підхід до формування міжкультурної комунікативної компетентності студентів-філологів. Актуальні проблеми педагогіки, психологї та професійної освіти. 2015. Т. 1. № 2. C. 64-69.

8. Костюк С. С. Розвиток компетентностей міжкультурної комунікації студентів-іноземців на основному етапі навчання української мови : автореф. дис. ... канд. пед. наук : 13.00.02. Кривий Ріг, 2018. 22 с.

9. Лапіна В. О. Критерії, дескриптори та рівні сформованості мовленнєвої компетентності студентів технічного вищого навчального закладу в процесі вивчення іноземних мов : зб. наук. праць I Міжнар. наук.-практ. конф. Переяслав-Хмельницький, 2012. С. 173-174. URL : http://oldconf.neasmo.org.ua/ node $/ 758$ (дата звернення 02.06.2018).

10. Нагорнюк Л. Є. Критерії сформованості іншомовної комунікативної компетенції майбутнього журналіста. URL : http://www. pdaa. edu. ua/np/pdf/83. pdf (дата звернення 02.06.2018).

11. Пальчикова О. О. Крос-культурна компетентність у навчанні української мови як іноземної. Філологічні студії : Науковий вісник Криворізького національного університету. Кривий Ріг : ТОВ “ОКТАНПРИНТ”, 2012. Вип. 8. С. 319-326.

12. Повесьма Н. В. Развитие социальной компетентности будущих специалистов железнодородного транспорта в вузе : дис. ... канд. пед. наук : 13.00.08. Челябинск, 2011. 224 с.

13. Практикум з методики викладання української мови в загальноосвітніх закладах : модульний курс : посібник для студентів пед. університетів та інститутів / за ред. М. І. Пентилюк. Київ : Ленвіт, 2011. 336 с.

14. Пригожина К. Б. Критерии оценки качества подготовки бизнесменов к межкультрной коммуникации. Вестник Московского государственного лингвистического университета. Вып. 3 (609). 2011. С. 157-165.

15. Пряжников Н. С. Психологический смысл труда : учеб. пособ. к курсу “Психология труда и инж. психология". акад. пед. и соц. наук ; Моск. психол.соц. ин-т. Москва : Ин-т практ. психологии ; Воронеж : НПО “МОДЭК”, 1997. $351 \mathrm{c}$.

16. Самойленко Н. Б. Теоретичні та методичні засади формування міжкультурної компетентності майбутніх фахівців гуманітарного профілю у вищих педагогічних навчальних закладах : автореф. дис. ... д-ра пед. наук : 13.00.04. Київ, 2014. 40 с. 
17. Словник української мови : в 11-и т. / за ред. І. К. Білодіда. Київ : Наук. думка, 1973.840 с.

18. Тернопільська В. І., Дерев'янко О. В. Визначення критеріїв сформованості професійної компетентності майбутніх гірничих інженерів. Науковий часопис Національного педагогічного університету імені М. П. Драгоманова. Серія 5. Педагогічні науки. 2010. Вип. 31. С. 264-267.

19. Хіценко Л. І. Критерії, показники та рівні сформованості соціокультурної компетентності. Педагогічні науки : зб. наук. праць. 2016. Вип. LXXIV. T. 1. С. 145-150.

20. Чумак Л. В. Полікультурне виховання учнів середніх (5-8) класів в умовах родинно-шкільного освітнього простору : автореф. дис. ... канд. пед. наук : 13.00.07. Тернопіль, 2011. 20 с.

\section{References}

1. Bakum Z. P., Palchikova A. A. Rol yazykovoj kartiny mira v obuchenii inostrannyh studentov ukrainskomu yazyku. Acta humanistica et scientifica universitatis sungio kiotiensis: materialy dokladov i soobshchenij Mezhdunarodnogo foruma "Sociokulturnye i filologicheskie aspekty v obrazovatelnom i nauchnom kontekste". Kioto : "Tanaka Print", 2014. S. 60-63.

2. Bloshchynskyi I. H. Obgruntuvannia kryteriiv i pokaznykiv efektyvnosti protsesu formuvannia adekvatnoi samootsinky kursantiv u navchalnomu protsesi VVZO. Naukovi zapysky. Vinnytsia : VAT "Vinobldrukarnia". 2001. Vyp. 4. S. 74 76.

3. Bulakh I. Ye. Suchasni pidkhody do vstanovlennia kryteriiu "sklav / ne sklav" $\mathrm{u}$ systemi amerykanskykh medychnykh litsenziinykh ispytiv. Pedahohika $i$ psykholohiia. 1997. № 3. S. 230-236.

4. Vereshchagin Ye.M., Kostomarov V. G. Yazyk i kultura : Lingvostranovedenie $\mathrm{v}$ prepodavanii russkogo yazyka kak inostrannogo. 4-e izd. Moskva : Rus. yaz., 1990. 246 s.

5. Dyrda I. A. Kryterii, pokaznyky ta rivni rozvytku polikulturnoi kompetentnosti studentiv-inozemtsiv u protsesi navchannia ukrainskoi movy. Filolohichni studii : Naukovyi visnyk Kryvorizkoho derzhavnoho pedahohichnoho universytetu : zb. nauk. prats. 2017. Vyp. 16. S. 459-465

6. Zozulia I. Ye. Polikulturne vykhovannia inozemnykh studentiv vyshchykh tekhnichnykh navchalnykh zakladiv : avtoref. dys. ... kand. ped. nauk : 13.00.07. Vinnytsia, 2012. $21 \mathrm{~s}$.

7. Zuienko N. O. Kryterialno-rivnevyi pidkhid do formuvannia mizhkulturnoi komunikatyvnoi kompetentnosti studentiv-filolohiv. Aktualni problemy pedahohiky, psykholohii ta profesiinoi osvity. 2015. T. 1. № 2. S. 64-69.

8. Kostiuk S. S. Rozvytok kompetentnostei mizhkulturnoi komunikatsii studentiv-inozemtsiv na osnovnomu etapi navchannia ukrainskoi movy : avtoref. dys. ... kand. ped. nauk : 13.00.02. Kryvyi Rih, 2018. 22 s.

9. Lapina V. O. Kryterii, deskryptory ta rivni sformovanosti movlennievoi kompetentnosti studentiv tekhnichnoho vyshchoho navchalnoho zakladu v protsesi vyvchennia inozemnykh mov : zb. nauk. prats I Mizhnar. nauk.-prakt. konf. 
Pereiaslav-Khmelnytskyi, 2012. S. 173-174. URL : http://oldconf.neasmo.org.ua/ node /758 (data zvernennia 02.06.2018).

10. Nahorniuk L. Ye. Kryterii sformovanosti inshomovnoi komunikatyvnoi kompetentsii maibutnoho zhurnalista. URL : http://www. pdaa. edu. ua/np/pdf/83. pdf (data zvernennia 02.06.2018).

11. Palchykova O. O. Kros-kulturna kompetentnist u navchanni ukrainskoi movy yak inozemnoi. Filolohichni studii: Naukovyi visnyk Kryvorizkoho natsionalnoho universytetu. Kryvyi Rih : TOV “OKTAN-PRYNT”, 2012. Vyp. 8. S. 319-326.

12. Povesma N. V. Razvytye sotsyalnoi kompetentnosty budushchykh spetsyalystov zheleznodorodnoho transporta $\mathrm{v}$ vuze : dys. ... kand. ped. nauk : 13.00.08. Cheliabynsk, 2011. $224 \mathrm{~s}$.

13. Praktykum z metodyky vykladannia ukrainskoi movy v zahalnoosvitnikh zakladakh : modulnyi kurs : Posibnyk dlia studentiv ped. universytetiv ta instytutiv / za red. M. I. Pentyliuk. Kyiv : Lenvit, 2011.336 s.

14. Pryhozhyna K. B. Kryteryy otsenky kachestva podhotovky byznesmenov k mezhkultrnoi kommunykatsyy. Vestnyk Moskovskoho hosudarstvennoho lynhvystycheskoho unyversyteta. Vyp. 3 (609). 2011. S. 157-165.

15. Priazhnykov N. S. Psykholohycheskyi smыsl truda : ucheb. posob. k kursu "Psykholohyia truda y ynzh. psykholohyia". akad. ped. y sots. nauk ; Mosk. psykhol.-sots. yn-t. Moskva : Yn-t prakt. psykholohyy ; Voronezh : NPO "MODEK", 1997. $351 \mathrm{~s}$.

16. Samoilenko N. B. Teoretychni ta metodychni zasady formuvannia mizhkulturnoi kompetentnosti maibutnikh fakhivtsiv humanitarnoho profiliu u vyshchykh pedahohichnykh navchalnykh zakladakh : avtoref. dys. ... d-ra ped. nauk : 13.00.04. Kyiv, 2014. $40 \mathrm{~s}$.

17. Slovnyk ukrainskoi movy : u 11 t. / za red. I. K. Bilodida. Kyiv : Nauk. dumka, 1973. $840 \mathrm{~s}$.

18. Ternopilska V. I., Derevianko O. V. Vyznachennia kryteriiv sformovanosti profesiinoi kompetentnosti maibutnikh hirnychykh inzheneriv. Naukovyi chasopys Natsionalnoho pedahohichnoho universytetu imeni M. P. Drahomanova. Seriia 5. Pedahohichni nauky. 2010. Vyp.31. S. 264-267.

19. Khitsenko L. I. Kryterii, pokaznyky ta rivni sformovanosti sotsiokulturnoi kompetentnosti. Pedahohichni nauky : zb. nauk. prats. 2016. Vyp. LXXIV. T. 1. S. $145-150$.

20. Chumak L. V. Polikulturne vykhovannia uchniv serednikh (5-8) klasiv v umovakh rodynno-shkilnoho osvitnoho prostoru : avtoref. dys. ... kand. ped. nauk : 13.00.07. Ternopil, 2011. $20 \mathrm{~s}$.

Стаття надійшла до редакиії 28.01.2019 p. Прийнята до друку 07.05. 2019 р. 